picture the process as one not wholly dissimilar; and this is what in one place we tried to do ; with, however, but poor success.

I have said that an electric current need be nothing more occult than is a charged sphere moving rapidly; and a good deal has been made out concerning currents by minutely discussing all that happens in such a case. But, even so, the problem is far from being a simple one. One has to consider not only the obviously moving charge, but also the opposite induced charge tied to it by lines of force (or tubes of induction, as they are sometimes called), and we have this whole complicated system in motion. And the effect of this motion is to set up a new phenomenon in the medium altogether-a spinning kind of motion that would not naturally have been expected; whereby two similarly charged spheres in motion repel one another less than when stationary, and may even begin to attract, if moving fast enough; whereby also a relation arises between electricity and magnetism, and the moving charged body deflects a cornpass needle. Of which more in the next Part.

$$
\text { (To be continued.) }
$$

\section{THE TWEEDDALE COLLECTION.}

THE great collection of birds formed by the late Marquess of Tweeddale has now safely arrived in London, and has been deposited in the Natural History Museum at South Kensington. It is sufficient to say that it equals in extent the valuable donation of American birds presented by Mr. Osbert Salvin and Mr. F. Du Cane Godman, numbering about 27,000 specimens; and though inferior in number of individual skins to the great Hume collection, which reached the phenomenal number of 63,000 specimens, it is not inferior in interest to either of these wonderful collections. Mr. Hume thoroughly worked the territory of the British Asian Empire from Scinde to Assam and Manipur, from Khatmandu to Ceylon, and from Tenasserim to Singapore; but to the eastward of these countries the work had been continued by other naturalists, and the results of their labours are largely represented in the Tweeddale collection, which now forms part of the British Museum.

On the death of the late Marquess, his entire collection and library were bequeathed by him to his nephew, Capt. R. G. Wardlaw Ramsay, of Whitehill, a naturalist of high promise and performance; and in the moment of satisfaction at receiving his magnificent donation one cannot help feeling great regret that the many cares and duties incident upon his succession to the family estates at Whitehill have temporarily deprived him of the leisure necessary for the working out of the great collection left to him by his uncle. The facilities for ornithological study, however, at the Natural History Museum, are now rapidly becoming so perfect that one may reasonably hope that he will, in common with all ornithologists, be able to work in that institution with the same comfort as in his own museum in Scotland. If in future years the student of birds finds that at South Kensington the work he loves can be done more expeditiously and with command of a larger series of specimens than in any other Museum in the world, his gratitude will be largely due to the four naturalists we have mentioned-Mr. Allan Hume, Messrs. O. Salvin and F. D. Godman, and Capt. Wardlaw Ramsay-for the unexampled generosity which has led them to present to the British nation the wonderful collections which will make our Ornithological Museum famous for all time.

Many naturalists who read this article will remember how, twelve years ago, the entire collection of bird-skins in the British Museum was contained in a few book-cases in a dingy cellar at Bloomsbury, where all the skins were kept in wooden boxes-a barbarous method, which was not only clumsy, but actually harmful to the specimens themselves. The development of the collection since that era is one which any English naturalist may consider with pride. Not only is the invaluable series of skins in the British Museum now well cared for and properly housed, but the raison d'etre of the large collections in private hands has been removed. It is admitted on all sides that had the facilities of study in the old days been such as they now are in the Natural History Museum, there would have been no need for ornithologists to devote their private means to the formation of the collections which have, however, now become the foundation of the greatest Ornithological Museum in the whole world.

The three great collections which have enriched the British Museum during the last two years have each been, in their way, of supreme importance for zoological science. The Hume collection was a perfect marvel in the way of complete series of specimens. Not only are the various plumages of the Indian birds exemplified in a manner hitherto unheard of, but even the geographical ranges of most of the species are illustrated in a perfect way by the series of specimens contained in the collection. The Salvin-Godman donation consisted of American birds, and added hundreds of species to the British Museum which were desiderata to that collection. Though not so rich in series of various plumages as the Hume collection, the number of gaps in the quota of American birds which their donation filled was simply enormous, and from being one of the most backward in regard to its neotropical collection of birds, the British Museum is now one of the foremost as regards the value of its American series.

The Tweeddale collection "takes up the running," so to speak, where Mr. Hume left off, and it must not be supposed that the donation now made by Capt. Wardlaw Ramsay is merely the collection of skins left to him by his uncle. 'To imagine this would be but a poor appreciation of the energy which has led him during the last few years to develop and greatly increase the collection by the addition of a large number of birds obtained during his military career in the East, and by hundreds of other valuable specimens acquired since his uncle's death. Thus the skins from the Kurrum Valley in Afghanistan, and from the Karen Hills in Burmah, obtained by Capt. Ramsay himself, are supplementary additions of the highest value to the Hume collection, inasmuch as Mr. Hume never had correspondents in these parts, and the specimens from the Andamans and Nicobars are also of great importance; but of course the interest of the Tweeddale collection centres round the expedition to the Philippine Archipelago made by $\mathrm{Mr}$. Alfred Everett for the late Marquess. Mr. Everett visited several islands on which no zoologist had previously trod, and as a natural result he discovered some beautiful new species of birds which are still unrepresented in any other collection but that of Capt. Ramsay. Altogether Mr. Everett furnished material for twelve important memoirs by the Marquess of Tweeddale, and the number of Philippine types now presented to the British Museum adds immensely to the wealth of the donation. Lord Tweeddale was also greatly interested in an obscure family of birds - the Drongos, or Crow-shrikes (Dicrurid(e)-and possessed a wonderful collection of these birds, although it may be stated that there is scarcely a family of Oriental birds which is not strongly and completely represented in the collection.

Ornithologists will understand the nature of this noble gift of Capt. Ramsay when they learn that in addition to the collection of birds he has also presented the whole of the splendid Tweeddale library (nearly 3000 volumes) to the British Museum, to be placed in the Bird-Room, alongside of the collection of skins, for the benefit of students of ornithology. The Tweeddale library is one of the best in the world, containing many rare volumes which 
we have not seen elsewhere, and this donation alone is worth several thousands of pounds. With a series of bird-skins now numbering nearly a quarter of a million, and with the best ornithological library in the world, it will be strange if the work done at the British Museum in future be not rendered an easy and an enjoyable task, though it must be remembered that the very magnitude of the collection contributes to the difficulty of its exact study. The writer may be excused an expression of deep gratitude to the ornithologists who have enriched the collection under his charge, so that from a series of (at the most) 40,000 skins, the number of bird-skins has been raised in fifteen years to more than 200,000 , and he merely adds a hope that he may see the British Museum become the repository of all the work of English ornithologists, not only from this country, but from all parts of the Empire.

This article has dealt merely with the three great donations which have been received during the last two years, and has not recorded the many other collections, of almost equal importance, which have been acquired by the Trustees of the British Museum since 1272 , the results of the life-work of such naturalists as Sclater, Wallace, Gould, and others of whom the country is proud, the acquisition of whose collections also is a source of the greatest encouragement to the writer.

R. BOWdLER SHARPE.

\section{THE STORM OF OCTOBER 30.}

THE gale which swept over the southern part of England on the morning of Sunday the 3oth was both sudden and severe. On the previous day the weather was exceptionally fine over the country generally, and in many places it was a truly "pet" day. The Meteorological Office, in their morning report referring to the barometric rise which was going on in the south and west; remarked that "some improvement in the weather is therefore likely in the south." In the afternoon of Saturday, however, there were signs of approaching bad weather, and by six o'clock a disturbance was shown to b? situated off Scilly, the barometer reading $29^{\circ} 4$ inches. The Meteoro logical Office considered the situation sufficiently menacing for the issue of storm signals, and the south cone was hoisted in the south and south-west districts. During the night the storm passed in an east-north-east direction over the southern counties of England, travelling at the rate of about thirty miles an hour. The centre passed almost directly over London at about five o'clock in the morning, when the wind changed suddenly about I $80^{\circ}$, the barometer at the time registering 28.86 inches, and in the next two hours the mercury rose 0.4 of an inch. At Greenwich Observatory the anemometer recorded $17^{\circ} 2 \mathrm{lbs}$ on the square foot at 7.5 a.m., which is equivalent to an hourly velocity of about sixty miles. By 8 a.m. the centre of the disturbance had passed to the eastward of our islands and was situated a short distance off Yarmouth. The storm afterwards travelled in a north-easterly direction, maintaining somewhat its former rate of movement, and on Monday morning the central area was in the neighbourhood of Stockholm. The gale was rather severe on our southern coasts, but its principal violence was felt in the English Channel and on the French and Danish coasts. The Paris Bulletin shows that at many of the stations the wind reached the full force of a hurricane, and the sea was terrific. The amount of rain which fell during the storm was unusually heavy, 1.59 inches being registered at Scilly, and upwards of an inch at other stations in the south of England and also in the north of France. As is commonly the case with these quick-travelling and rapidly-developing storms, the disturbance was a "secondary" to a larger disturbance which was passing from off the Atlantic to the north ward of our islands.

\section{ROBERT HUNT, F.R.S.}

M R. ROBERT HUNT, whose death we have already I briefly announced, was born at Devonport, then called Plymouth Dock, on September 6, 1807 . His father was a naval officer who perished, with all the crew, in H.M.S. Moucheron, in the Grecian Archipelago. Robert Hunt, left to his mother's care, was destined for the medical profession; and, having been placed with a surgeon in London, he attended the anatomical lectures of Joshua Brooks; but his studies were interrupted by failing health, and his medical training was never completed. In I 840, Mr. Hunt became secretary to the Royal Cornwall Polytechnic Society at Falmouth. His earliest contributions to science were in connection with photography-a subject to which he applied himself with assiduity immediately on the announcement of Daguerre's discovery in 1839. Mr. Hunt's investigations led to the discovery of several new processes, which were either described in the Philosophical Magazine or announced to the British Association. His experimental researches on the chemical activity of the highly refrangible rays of the solar spectrum, his work with the actinograph, and his study of the influence of light upon the germination of seeds and the growth of plants, formed the subject of numerous papers between 1840 and I 854 . Mr. Hunt's "Researches on Light" appeared in I 844. His "Manual of Photography," which was the first general work on the subject published in this country, passed through six editions.

While Mr. Hunt was in Cornwall he undertook some interesting inquiries, conjointly with the late $\mathrm{Mr}$. Robert Were Fox, into the electrical phenomena of mineral veins; and he also entered upon an examination of the air in some of the Cornish mines. In I 845 he came to London, at the invitation of Sir H. T. De la Beche, to succeed $\mathrm{Mr}$. Thomas Jordan, as Keeper of Mining Records at the Museum of Economic Geology, then recently established in Craig's Court. On the establishment of the Government School of Mines in I 85 I, he was appointed Lecturer on Mechanical Science, and opened his course with an address on the importance of cultivating habits of observation. After holding this position for two sessions he resigned it to the late Prof. Willis, and undertook for a short time the duties of Lecturer on Physics. In $1854 \mathrm{Mr}$. Hunt was elected a Fellow of the Royal Society.

For the last thirty years Mr. Hunt's energies have been mainly directed to the collection and collation of statistical information relating to British mining and metallurgy. From 1853 until the abolition of the Keepership of Mining Records he published regularly the annual volumes of "Mineral Statistics," containing a vast mass of voluntary returns obtained by his personal influence. As a member of the Royal Coal Commission of 1866 , he undertook the statistical part of the inquiry, and published detailed information on the coal resources of the country.

The technical education of the metal-mining population of the West of England was a subject that Mr. Hunt always had at heart. He was an earnest advocate for the estublishment of local mining schools, and should be regarded practically as the founder of the Miners' Association of Cornwall and Devon-a body now amalgamated with the Mining Institute. In 1883 , Mr. Hunt published a voluminous work on "British Mining." After the death of Dr. Ure he consented to edit the "Dictionary of Arts," an 1 brought out successively the fifth (I860), sixth (I 867), and seventh (I 875) editions of this work. At the same time Mr. Hunt possessed great literary taste, which found scope in several lighter works, such as his "Poetry of Science," "Panthea, or the Spirit of Nature," and the "Romances of the West of England." Mr. Hunt's long, busy, and useful life was closed on the $17^{\text {th }}$ ult. His remains were interred in Brompton Cemetery. 